\title{
Processing of Specific Sorghum Genotypes for Semolina Recovery and their Nutrient Composition
}

\begin{abstract}
Bhukya Ranga $^{1}$, Venkata Chamarthy Ratnavathi ${ }^{1 *}$, Vilas A Tonapi ${ }^{1}$ ${ }^{1}$ ICAR-Indian Institute of Millets Research, Rajendranagar, Hyderabad-500 030, Telangana, India

Article History

Received: 23.02.2021

Accepted: 03.03.2021

Published: 08.03.2021

Journal homepage:

https://www.easpublisher.com

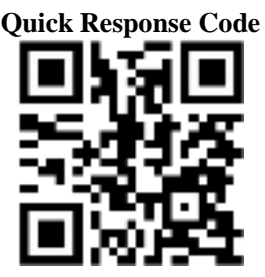

Abstract: Today's agriculture programme demands production of designer foods which is beneficial both to producers and consumer. Agriculture requires transformation from subsistence farming to consumer demand oriented one with good market and income generation approach. Sorghum with its diverse end uses is one such food which can play significant role and be profitable to farmers. In the present study, 60 sorghum genotypes were evaluated over two seasons to identify genotypes suitable for semolina recovery, endosperm texture efficiency and proximate composition. Semolina recovery, percent starch and percent protein had significant $(\mathrm{p} \leq 0.0001)$ association with white, brown and red sorghum genotypes. Semolina recovery ranged from $36.17 \%$ to $66.55 \%$, whereas starch ranged from $52 \%$ to $66.25 \%$ and protein ranged from $7.3 \%$ to $12.35 \%$. Similarly nonsignificant deference was observed with endosperm texture in brown and red sorghum genotypes and ranged from $25 \%$ to $100 \%$. Mean \pm standard deviation (SD) values were calculated for white, red, and brown sorghum genotypes. In this study, the information given and the genotype identified will help in enhancing the demand for sorghum as a beneficial industrial crop.

Keywords: Sorghum, Starch content, Protein content, Semolina, Endosperm texture.
\end{abstract}

Copyright () 2021 The Author(s): This is an open-access article distributed under the terms of the Creative Commons Attribution 4.0 International License (CC BY-NC 4.0) which permits unrestricted use, distribution, and reproduction in any medium for non-commercial use provided the original author and source are credited.

\section{INTRODUCTION}

Sorghum stands for staple food in semi-arid regions worldwide. Most of the countries produced sorghum grain from kharif season (rainy season) can be polished with pearling machine and used for traditional food products like cakes, bread and biscuits. In India, most of the sorghum produced is consumed as roti or chapatti (unleavened flat bread) [1]. On the other hand, the sorghum that is harvested in the rabi (post-rainy season) is of superior quality and used only for food. Sorghum is commonly called as jowar or great millet and also considered as coarse grain due to the presence of outer fibrous bran of seeds. Sorghum is rich in leucine but poor in lycine.

In India, sorghum production is 1.85 million tons during 2019-2020 [2]. High yielding varieties and hybrids has been improved with agronomic traits that resulted in excess production. [3]. Sorghum constitutes a source of minerals, proteins and calories so that about 700 million people are nourished by sorghum and sorghum protein is superior compared to wheat in protein digestibility and biological value. Millets, sorghum and pulses are used as staple grains for house hold consumption [4].
Grain sorghum can also be processed to develop different end products such as flours, semolina, alcoholic beverages, pet foods and packaging materials [5]. Sorghum grain with hard endosperm texture is more suited for the semolina (rava) preparation and determines the milling quality and quantity of end product [6]. Sorghum processed food products are emerging for human consumption such as flakes, vermicelli, pasta etc [7].

Sorghum is available in three colours as red, white and brown, recently red variety has been developed for food use [8]. Sorghum is a gluten free grain and it has good source of nutrients such as fibre, micronutrients, antioxidant phenolics and cholesterollowering waxes [9]. Sorghum products usually have a shelf-life of over one year. A few important sorghum products are sun dried papad, badi and kurdigai. These can be available through marketing channels and those are used similar to rice products. If the technology for specific industrial end uses are developed, sorghum could be in abundant demand in the future [10].

Semolina is easy to prepare and consume and they make most popular food products of sorghum, dedicated grain proximate compositional evaluation programs for improved grain quality towards specific 
end product, without compromising for yield form the basis of link between farm products and industry.

In the present study, we have generated information on end-product specific genotypes by studying i) the relative contribution of genotypes and ii) understanding the relationship between associated grain quality traits and yield, and iii) identifying the potential genotypes that can be used in the proximate analysis programs aimed at development of genotypes suitable for high semolina recovery and endosperm texture efficiency.

\section{Material ANd Methods \\ Plant Material}

The grains of 60 sorghum (Sorghum bicolor (L.) Moench) genotypes were used in this study including the germplasm lines, improved lines, parental hybrids and cultivated lines, belonging to different races from different countries. Out of 60 genotypes, 36 were white-grained, 17 had red grains and 7 had brown grains (Table-1). The material includes some major sorghum varieties ('CSV 13', 'CSV 15') and one check
(C-43) was used for nutritional properties. The list of the genotypes included in the present study are provided in (Table-1). These genotypes were sown in randomized complete block design (RCBD) with two replications, each with two rows of $5 \mathrm{~m}$ length for two consecutive years (2012-2013) during rainy and post-rainy seasons at Indian Institute of Millet Research, Rajendranagar, Hyderabad, India. The colour of the grain was recorded visually based on the colour of pericarp. The crop was harvested at the panicle (ear head) maturity stage. Panicles were threshed for grain and $200 \mathrm{~g}$ grain was used for experimental purpose. Whole grain was stored at $4{ }^{\circ} \mathrm{C}$ for further analysis.

\section{Chemicals}

AR grade solvents and Millipore distilled water (Merck-Millipore, Synergy, UV plus) were used in the analysis. The chemicals phenol, sulphuric acid, sodium acetate, ethanol, glucose, salicylate, ammonium chloride were purchased from Sisco Research Laboratories, Mumbai, India. Amyloglucosidasge was purchased from Sigma-Aldrich, U.S.A. All the chemicals were of analytical grade.

Table-1: List of the genotypes included in the study

\begin{tabular}{|l|l|l|l|}
\hline $\begin{array}{l}\text { S. } \\
\text { No }\end{array}$ & Genotype name & Group & $\begin{array}{l}\text { Colour } \\
\text { of grain }\end{array}$ \\
\hline 1 & 27B (1), 296B (2), 463B (3), 7B (4), AKMS 14B (5), IMS 9B (15) & $\begin{array}{l}\text { Female parents of Released } \\
\text { hybrids }\end{array}$ & $\begin{array}{l}\text { White } \\
\text { grain }\end{array}$ \\
\hline 2 & $\begin{array}{l}\text { AKR 150 (6), AKR 354 (7), C 43 (8), I 12 (14), RS 627 (20), RS } \\
673(21)\end{array}$ & $\begin{array}{l}\text { Male parents of Released } \\
\text { hybrids }\end{array}$ & $\begin{array}{l}\text { White } \\
\text { grain }\end{array}$ \\
\hline 3 & CSV 13, (9), CSV 15 (10) & Released cultivars & $\begin{array}{l}\text { White } \\
\text { grain }\end{array}$ \\
\hline 4 & $\begin{array}{l}\text { IC345194 (11), IC305903 (12), IC305923 (13), IS 33648 (17), IS } \\
40751(18), \text { IS 18035 (38) }\end{array}$ & Germplasm lines & $\begin{array}{l}\text { White } \\
\text { grain }\end{array}$ \\
\hline 5 & $\begin{array}{l}\text { SPV 1258 (22), SPV 1293 (23), SPV 1471 (24), SPV 1606 (25), } \\
\text { SPV 1616 (26), SPV 1731 (27), SPV 1732 (28), SPV 1733 (29), } \\
\text { SPV 1734 (30), SPV 1750 (31), SPV 1760 (32), SPV 1775 (33), } \\
\text { SPV 459 (34), SPV 462 (35), SPV 711 (36), SPV 933 (37), }\end{array}$ & $\begin{array}{l}\text { Improved lines from All } \\
\text { India Co-ordinated Research } \\
\text { (AICRP-Sorghum }\end{array}$ & grain \\
\hline 6 & $\begin{array}{l}\text { IS 31681 (16), IS 4372 (19), IS 1212 (39), IS 1206 (40), IS 12735 } \\
\text { (41), IS 16151 (42), IS 20298 (43), IS 20743 (44), IS 23514 (45), }\end{array}$ & Germplasm lines & $\begin{array}{l}\text { Red } \\
\text { grain }\end{array}$ \\
\hline 7 & $\begin{array}{l}\text { IS 2389 (46), IS 28141 (47), IS 28313 (48), IS 29241 (49), IS } \\
\text { IS 12697 (50), IS 30533 (51), IS 3158 (52), IS 4060 (53) }\end{array}$ & & \\
\hline 30466 (58), IS 30508 (59), IS 715 (60) & & $\begin{array}{l}\text { Brown } \\
\text { grain }\end{array}$ \\
\hline
\end{tabular}

\section{Grain yield and milling traits \\ Semolina recovery (SER)}

$200 \mathrm{~g}$ of sorghum grain from each genotype in each replication was taken then cleaned and was kept in oven at $40{ }^{\circ} \mathrm{C}$ for $30 \mathrm{~min}$ to equilibrate moisture content in the grain samples. Then the grain was milled in the grinding machine (Natraj domestic flour mill, India), using sieve number 3 with pore size of $700 \mu \mathrm{m}$. Semolina (rava) was obtained after grinding and was weighed. The percentage of semolina was calculated using the initial weight of grain $(200 \mathrm{~g})$. From the ground sample, the semolina was subjected to purification and separated by using different sieves.
Biochemical analysis of semolina was done for percent starch and percent protein using standard methods [9].

\section{Endosperm texture (ENT)}

Endosperm texture was analysed by visual assessment on ten sorghum grains in each plant according to the DUS guidelines of sorghum [11]. Initially the sorghum seeds were soaked for 1 hour and were sectioned longitudinally and visual observation was done on percentage of vitreous (corneous) endosperm. The data was recorded as $25 \%$ vitreous, $50 \%$ vitreous, $75 \%$ vitreous and $>90 \%$ vitreous. Data 
was recorded on ten plants in each genotype and average values were used for further analysis.

\section{Grain biochemical quality traits Starch content (\%)}

Starch content was estimated by using method Southgate [12] with some modifications. Defatted sorghum flour $(75 \mathrm{mg})$ was taken and it was autoclaved for $90 \mathrm{~min}$ at $19 \mathrm{lbs}$ pressure. The content was hydrolysed using the enzyme amyloglucosidase $(25 \mathrm{mg}$ contains 5.75 units $/ \mathrm{mg}$ ) and $2 \mathrm{M}$ sodium acetate buffer was added. The hydrolysed sugars were estimated after diluting the extract with Millipore distilled water by phenol-sulphuric acid method [13] and the absorbance was read at $490 \mathrm{~nm}$ in a UV-Spectrophotometer (Schimadzu, Japan). Percent starch content was calculated by using 0.9 as conversion factor for sugars.

\section{Protein content $(\%)$}

Total protein content was estimated by using colorimetric determination of total Kjeldhal nitrogen using salicylate [14]. Defatted grain sorghum flour (100 mg) accurately weighed (Mettler balance, Austria) into digestion tube with concentrated sulphuric acid and the mixture was digested for one hour at $425{ }^{\circ} \mathrm{C}$ in digestor (Gerhardt, Germany). Sample was converted to ammonia (Kjeldhal nitrogen) and absorbance was read at $685 \mathrm{~nm}$. Ammonium chloride was used as a reference standard with a concentration range of $1-20 \mu \mathrm{g} / \mathrm{ml}$ (nitrogen). The amount of protein was calculated by multiplying the amount of nitrogen obtained with a factor 6.25 (N X 6.25).

\section{Statistical Analyses}

All replication wise data are presented as mean \pm standard deviation (SD). The significant difference was calculated using one way ANOVA, and the $\mathrm{P}$ value was set at $* \mathrm{P} \leq 0.05, * * \mathrm{P} \leq 0.01, * * * \mathrm{P} \leq 0.001, * * * * \mathrm{P} \leq$ 0.0001 .

\section{ReSUlT AND DisCUSSION}

Proximate composition of sorghum genotypes are given in the table [15]. The starch content showed significant $(\mathrm{p} \leq 0.0001)$ difference between white, red and brown sorghum genotypes. Highest starch content was seen in the genotype C-43 (66.25\%) compared to red sorghum genotype IS $30533(63.3 \%)$ and brown sorghum genotype IS $715(62.85 \%)$. Starch content of white sorghum genotype ranged from 52\% in RS 673 to $66.25 \%$ in C-43 and red sorghum genotype ranged from $57.55 \%$ in IS 4060 to $63.3 \%$ in IS 30533 whereas in brown sorghum genotype, it ranged from $56.55 \%$ in IS20697 to $62.85 \%$ in IS 715 genotype (Table-2). Among white, red and brown sorghum genotypes, lowest starch content was recorded as $52 \%$ in the white sorghum genotype RS 673. Similarly mean \pm standard deviation (SD) values was calculated for starch content in white, red, and brown sorghum genotypes as $60.2 \%$, $60.5 \%$ and $59.3 \%$ (Table-2). Significant progress is observed in the sorghum genetics since nineties. Physical and biochemical grain quality constitution have been studied [16, 17]. Starch is the main component in all the cereals, [18] and it was reported that the proximate composition of starch content in the sorghum-wheat flour biscuits ranged from $63.32 \%$ to $70.65 \%$, the variation is due to type of cultivar and difference in the process variables. According to [19] the starch and fiber content of pure sorghum cookies were $73.73 \%$ and $2.24 \%$ respectively.

The protein content showed significant $(\mathrm{p} \leq 0.001)$ difference between white, red and brown sorghum genotypes. The protein content in sorghum grain ranged from $7.3 \%$ to $12.35 \%$, and IS 12706 red sorghum genotype gave a significantly higher level of protein content $12.35 \%$ par with the white sorghum genotype IC345194 which showed protein content $12.25 \%$, whereas low level of protein content was recorded as $7.3 \%$ in the brown sorghum genotype IS30508. Similarly mean \pm standard deviation (SD) values was calculated for protein content in white, red, and brown sorghum genotypes as 9.9\%, 9.3\% and $10.3 \%$ respectively (Table-2). Protein content in sorghum ranged from $9.6 \%$ to $14 \%$ and it was reported that crude protein in sorghum ranged from $9.14 \%$ to $13 \%$ [20-22]. Semolina recovery showed significant $(\mathrm{p} \leq 0.0001)$ difference between white, brown and red, brown sorghum genotypes, whereas non-significant difference was observed between white and red sorghum genotypes for semolina recovery. The range observed was $36.17 \%$ to $66.55 \%$ over the season with the genotype SPV933 white sorghum genotype expressing high recovery $(66.55 \%)$. In the red sorghum genotypes, the semolina recovery ranged from $44.20 \%$ (IS12735) to $59.48 \%$ (IS23514), whereas in the brown sorghum genotypes, it ranged as $38.35 \%$ (IS23992) to $50.29 \%$ (IS20697) respectively. Similarly, low level of semolina recovery was recorded as $36.17 \%$ in the white sorghum genotype AKMS14B. For semolina recovery in white, red and brown sorghum genotypes, mean \pm standard deviation (SD) values were calculated as $48.47 \%, 45.10 \%$ and $48.48 \%$ respectively (Table-2). Semolina from sorghum grain is the good source of calcium, iron, phosphorus, potassium and other minor elements $[10,23]$. Semolina is the coarse part of the grain which is used in different food preparations. Genotypes suitable for semolina can also be used for making further sorghum products. [24] Reported that vitreous (corneous) endosperm expands while floury endosperm remains intact and genotype with corneous (hard) endosperm is more suitable for semolina preparation [1].

Endosperm texture among the genotypes had variation from $25 \%$ to $100 \%$ vitreousness. Genotypes with $100 \%$ vitreousness are considered as best genotypes. 27B, IC305923, IS33648, IS4372, SPV1750 and IS30533 white and red sorghum genotypes had shown $100 \%$ vitreousness. Endosperm texture showed 
significant $(\mathrm{p} \leq 0.0001)$ difference between white vs. red and white vs. brown sorghum genotypes, whereas nonsignificant difference was observed between red vs. brown sorghum genotypes. Mean \pm standard deviation
(SD) values was calculated for endosperm texture in white, red and brown sorghum genotypes as $56.5 \%$, $44.6 \%, 49.1 \%$ respectively (Table- 2 ).

Table-2: Grouping of the sorghum genotypes and mean performance

\begin{tabular}{|c|c|c|c|c|c|}
\hline \multirow{2}{*}{$\begin{array}{l}\text { Genotype } \\
\text { Red sorghum } \\
\end{array}$} & \multirow{2}{*}{$\begin{array}{l}\text { Traits } \\
\text { Recovery (\%) }\end{array}$} & \multicolumn{3}{|c|}{$\begin{array}{l}\text { Performance of the } \\
\text { genotype for the trait }\end{array}$} & \multirow[t]{2}{*}{ Best five genotypes } \\
\hline & & Mean & Min & Max & \\
\hline \multirow{4}{*}{$\begin{array}{l}\text { IS31681, IS4372, IS1212, IS1206, IS12735, } \\
\text { IS16151, IS20298, IS20743, IS23514, IS2389, } \\
\text { IS28141, IS28313, IS29241, IS29950, IS30533, } \\
\text { IS3158, IS4060 }\end{array}$} & Semolina & 45.1 & 44.2 & 59.4 & $\begin{array}{l}\text { IS23514, IS29950, IS29241, } \\
\text { IS28313, IS4060 }\end{array}$ \\
\hline & Starch content & 60.5 & 57.55 & 63.3 & $\begin{array}{l}\text { IS30533,IS16151, IS23514, } \\
\text { IS28141, IS29950 }\end{array}$ \\
\hline & Protein content & 9.3 & 9 & 12.35 & $\begin{array}{l}\text { IS12706, IS4060, IS1212, } \\
\text { IS28313, IS29950 }\end{array}$ \\
\hline & $\begin{array}{l}\text { Endosperm } \\
\text { texture }\end{array}$ & 44.6 & 25 & 100 & $\begin{array}{l}\text { IS30503, IS20743, IS2389, } \\
\text { IS28313,IS1212 }\end{array}$ \\
\hline White sorghum & Recovery $(\%)$ & & & & \\
\hline \multirow{4}{*}{$\begin{array}{l}\text { 27B, 296B, 463B, 7B, AKMS14B, IMS 9B, } \\
\text { AKR150, AKR354, C 43, I12, RS627, } \\
\text { RS673,CSV13,CSV15, IC345194, IC305903, } \\
\text { IC305923, IS33648, IS40751, IS18035, } \\
\text { SPV1258, SPV1293, SPV1471, SPV1606, } \\
\text { SPV1616, SPV1731, SPV1732, SPV1733, } \\
\text { SPV1734, SPV1750, SPV1760, SPV1775, } \\
\text { SPV459, SPV462, SPV711, SPV933, }\end{array}$} & Semolina & 48.4 & 36.1 & 66.5 & $\begin{array}{l}\text { SPV933, SPV1616, } \\
\text { SPV1471, I12, CSV13 }\end{array}$ \\
\hline & Starch content & 60.2 & 52 & 66.25 & $\begin{array}{l}\text { C-43, IMS9B, AKR150, } \\
\text { 463B, IC305903 }\end{array}$ \\
\hline & Protein content & 9.9 & 8 & 12.25 & $\begin{array}{l}\text { IC345194, IMS9B, } \\
\text { SPV1258, SPV1750, } \\
\text { SPV1731 }\end{array}$ \\
\hline & $\begin{array}{l}\text { Endosperm } \\
\text { texture }\end{array}$ & 56.5 & 25 & 100 & $\begin{array}{l}\text { 27B, IC305923, IS33648, } \\
\text { IS4372, SPV1750 }\end{array}$ \\
\hline Brown sorghum & Recovery $(\%)$ & & & & \\
\hline \multirow[t]{4}{*}{$\begin{array}{l}\text { IS12697, IS20697, IS23992, IS24462, IS 30466, } \\
\text { IS30508, IS715 }\end{array}$} & Semolina & 48.4 & 38.5 & 50.2 & $\begin{array}{l}\text { IS20697, IS12697, IS30466, } \\
\text { IS24462, IS715 }\end{array}$ \\
\hline & Starch content & 59.3 & 56.55 & 62.8 & $\begin{array}{l}\text { IS715, IS23992, IS24462, } \\
\text { IS30466, IS12697 }\end{array}$ \\
\hline & Protein content & 10.38 & 7.3 & 11.25 & $\begin{array}{l}\text { IS23992,IS30466,IS715, } \\
\text { IS20697,IS24462 }\end{array}$ \\
\hline & $\begin{array}{l}\text { Endosperm } \\
\text { texture }\end{array}$ & 49.1 & 25 & 75 & $\begin{array}{l}\text { IS12697, IS24462, } \\
\text { IS30508, IS23992, IS715 }\end{array}$ \\
\hline
\end{tabular}

\section{CONCLUSION}

The sorghum genotypes evaluated in this study exhibited considerable proximate variability, semolina recovery and endosperm texture. Higher genotypic variability was observed for many of the traits studied. It would be possible to utilize the variation identified in sorghum improvement programs aimed at development of cultivars with high semolina recovery and proximate composition without compromising on productivity. The identified best sorghum genotypes will play a major role in enhancing the demand for sorghum as a beneficial industrial crop. With the availability of end product specific genotypes, farmers are benefitted with premium price and supply of superior quality raw material. Farming of identity-preserved-genotypes satisfies the demand and supply chain of industries.

\section{Acknowledgement}

The authors acknowledge Department of biotechnology (DBT) for funding this research at IIMR.

\section{REFERENCES}

1. Ratnavathi, C. V., \& Patil, J. V. (2013). Sorghum utilization as food. Journal of Nutrition \& Food
Sciences, 4, 247. https://doi.org/10.4172/21559600.1000247.

2. GOI. (2011). Agriculture Statistics at a Glance. Directorate of Economics and Statistics. New Delhi.

3. Chavan, U. D., Patil, S. S., \& Patil, J. V. (2015) Processing Of Sorghum From Different Varieties And Hybrids For Semolina And Their Products: Indonesian Journal of Agricultural Science, 16, 11-20.

4. Dayakar Rao, B. N., Seetharama, Elangovan, M., Tonapi, A. V., \& Ratnavathi, C. V. (2007). Changing Scenario of Millets Cultivation in India. Souvenir, Farm Fest, February at Uppalam, Puducheri: 23-25.

5. Aruna, C., \& Visarada, K. B. R. S. (2019). Other industrial uses of sorghum. In: Aruna C, Visarada KBRS, Bhat BV, Tonapi VA. (Eds.), Breeding Sorghum for Diverse End uses. Wood head publishing, UK: First ed. pp. 271-292.

6. Audilakshmi, S., \& Aruna, C. (2005). Genetic analysis of physical grain quality characters in sorghum. Cambridge University Press. Journal of Agricultural Science, 143, 267-273. 
7. Dayakar Rao, B., \& Singh, J. P. (2010). Status paper on millets in India. Background paper prepared for National Seminar on Millets, organized by Directorate of Millets Development, Jaipur and Directorate of Sorghum Research, Hyderabad.

8. Sanddhya, N. S., Meera, M. S., \& Bhattacharya, S. (2013). Effect of popping on sorghum starch digestibility and predicted glycemic index. Journal of Food Science and Technology, 50, 387-392.

9. Aruna, C., Suguna, M., Visarada K. B. R. S., Deepika, C., Ratnavathi, C. V., \& Tonapi, V. A. (2020). Identification of sorghum genotypes suitable for specific end uses: Semolina recovery and popping. Journal of Cereal Science, 93(2020), 102955.

10. Chavan, U. D., \& Patil, J. V. (2010). Grain Processing of Sorghum. Ibdc Publishers, Lucknow. pp. 10-15.

11. http://www.plantauthority.gov.in/pdf/RevisedSorghum.pdf-accessed on 21st February, 2020.

12. Southgate, D. A. T. (1976). On Determination of Food and Carbohydrates. Applied Science Publishers Ltd. Pp. 52-55. London; UK.

13. Dubois, M., Gilles, K. A., Hamilton, J. K., Rebers, P. A., \& Smith, F. (1956). Colorimetric method for determination of sugars and related substances. Analytical Chemistry, 28, 350-356.

14. Willis, R. B., Montgomery, M. E., \& Allan, P. R. (1996). Improved method for manual, colorometric determination of total Kjeldahl nitrogen using salicylate. Journal of Agricultural and Food Chemistry, 44, 1804-1807.

15. Hulse, J. H., Liang, E. M., \& Pearson, O. E. (1980). Sorghum and the Millets: their composition and nutritional value. London, Academic Press.

16. Boyles, R. E., Pfeiffer, B. K., Cooper, E. A., Rauh, B. L., Zielinski, K. J., Mayers, M. T, Brenton, Z., Rooney, W. L., \& Kresovich, S. (2017). Genetic dissection of sorghum grain quality traits using diverse and segregating populations. Theoretical and applied Applied Genetics, 130,697-716.

17. Guindo, D., Teme, N., Vaksmann, M., Doumbia, M., Vilmus, I., Guitton, B., Sissoko, A., Mestres, C., Davrieux, F., Fliedel, G., Kouressy, M., Courtois, B., \& Rami, J. F. (2019). Quantitative trait loci for sorghum grain morphology and quality traits: toward breeding for a traditional food preparation of West-Africa. Journal of Cereal Science, 85, 256-272.

18. Adebowale, A. A., Adegoke, M. T., Sanni, S. A., Adegunwa, M. O., \& Fetuga, G. O. (2012). Functional Properties and Biscuit Making Potentials of Sorghum-wheat Flour Composite. American Journal of Food Technology, 7, 372379.

19. Okpala, L. C., \& Okoli, E. C. (2011). Nutritional evaluation of cookies produced from pigeon pea, cocoyam and sorghum flour blends. African Journal of Biotechnology, 10, 433-438.

20. Chavan, U. D., Patil, J. V., \& Shinde, M. S. (2009). Nutritional and roti quality of sorghum genotypes. Indonesian Journal of Agricultural Science, 10, 80-87.

21. Ratnavathi, C. V., Bala, S. R., Subramanian, V., \& Rao, N. S. (2000). A study on the suitability of unmalted sorghum as a brewing adjunct. Journal of the Institute of Brewing, 106, 383-387.

22. Robertson, S. K., \& Perez-Maldonado, R. A. (2006). Nutritional characteristics of sorghum from QLD AGd NSW. The Australian Poultry Science Symposium, 2006-18.

23. Winchester, M. D., \& Makokha, A. O. (2011). Mineral contents in grain sorghum. African Journal of Food Science, 5, 436-445.

24. Vazquez-Carrillo, M. G., Santiago-Ramos, D., \& Figueroa-Cardenas, J. D. (2019). Kernel properties and popping potential of Chapalote, Mexican ancient native maize. Journal of Cereal Science, $86,69-76$.

Cite This Article: Bhukya Ranga et al (2021). Processing of Specific Sorghum Genotypes for Semolina Recovery and their Nutrient Composition. EAS J Nutr Food Sci, 3(2), 21-25. 